\begin{tabular}{|l|l|l||}
\hline \multicolumn{2}{|c|}{ PublisherInfo } \\
\hline \hline PublisherName & $:$ & BioMed Central \\
\hline \hline PublisherLocation & $:$ & London \\
\hline \hline PublisherImprintName & $:$ & BioMed Central \\
\hline \hline
\end{tabular}

\title{
Comparing cows with humans
}

\begin{tabular}{|l|l|l||}
\hline \multicolumn{2}{|c|}{ ArticleInfo } \\
\hline \hline ArticleID & $:$ & 3789 \\
\hline \hline ArticleDOI & $:$ & $10.1186 /$ gb-spotlight-20001005-04 \\
\hline \hline ArticleCitationID & $:$ & spotlight-20001005-04 \\
\hline \hline ArticleSequenceNumber & $:$ & 226 \\
\hline \hline ArticleCategory & $:$ & Research news \\
\hline ArticleFirstPage & $:$ & 1 \\
\hline \hline ArticleLastPage & $:$ & 2 \\
\hline \hline & $:$ & RegistrationDate : 2000-10-05 \\
ArticleHistory & $:$ & OnlineDate $: 2000-10-05$ \\
\hline \hline ArticleCopyright & $:$ & BioMed Central Ltd2000 \\
\hline \hline ArticleGrants & $:$ & \\
\hline \hline ArticleContext & $:$ & 130591111 \\
\hline \hline
\end{tabular}




\section{Jonathan B Weitzman}

Email: jonathanweitzman@hotmail.com

Comparative genomics is emerging as a powerful approach for assessing the similarities and differences between species. In the September Genome Research Band et al. compare cows and humans to generate mapping information about the bovine genome (Genome Res 2000, 10:1359-1368). The authors combined parallel radiation hybrid (RH) mapping analysis with express sequence tag (EST) sequence information and a bioinformatic methodology called COMPASS (comparative mapping by annotation and sequence similarity). They were able to create a whole-genome RH map with 768 cattle genes and 319 anchored microsatellite markers. Over $80 \%$ of these genes had human orthologs and the two genomes had at least 105 conserved chromosomal segments in common. The coverage of the cattlehuman comparative map is predicted to be about $60 \%$. These results provide a framework for future comparative studies. Clearly men and cows are more similar than they look.

\section{References}

1. The promise of comparative genomics in mammals.

2. Genome Research, [http://www.genome.org]

3. Bovine Genome, [http://bos.cvm.tamu.edu/bovgbase.html]

4. COMPASS, [http://cagst.animal.uiuc.edu/genemap/] 